\title{
Level of Awareness of Gram Panchayat Members about Agricultural Development Programmes in Uttar Pradesh
}

\author{
Ramvinay Pal ${ }^{1}{ }^{*}$, H. C. Singh ${ }^{2}$, Shashank Shekhar Singh ${ }^{3}$ and Sunil Kumar ${ }^{1}$ \\ ${ }^{1}$ Department of Extension Education, C.S. Azad University of Agriculture \& Technology, \\ Kanpur-208002, (UP), India \\ ${ }^{2}$ Department of Extension Education, Faculty of Agricultural Engineering \& Technology, \\ Campus, Etawah, Uttar Pradesh, India \\ ${ }^{3}$ Department of Extension Education, Sardar Vallabhbhai Patel University of Agriculture \& \\ Technology, Meerut, Uttar Pradesh, India \\ *Corresponding author
}

\section{A B S T R A C T}

\begin{tabular}{|l|} 
Ke y w or d s \\
$\begin{array}{l}\text { Awareness, Gram } \\
\text { Panchayat Members }\end{array}$ \\
\hline Article Info \\
\hline $\begin{array}{l}\text { Accepted: } \\
\text { 20 September } 2020 \\
\text { Available Online: } \\
\text { 10 October } 2020\end{array}$ \\
\hline
\end{tabular}

The present study was undertaken with the specific objective to know the level of awareness of Gram Panchayat Members in agricultural development in Uttar Pradesh. From the present study, it was concluded that the maximum number of respondent $(60 \%)$ were found having medium level of awareness about agriculture development programmes followed by high level $(22.5 \%)$ and low level (17.5\%), respectively.

\section{Introduction}

The elected members of Gram Panchayat are formal leaders and accepted by the local people. Gram Panchayat members play important role in village developmental activities. India's ever increasing population has to be fed by increased food production. Improved agriculture production technologies should be employed or adopted in rural areas of farming. Government runs many agricultural development programmes to enhance the growth in agricultural production.
These programmes should reach to the bottom of the farmers' field in villages, that's why to spread and adopt the agricultural development programmes they should firstly be adopted by Gram Panchayat members the ultimate leaders of villagers so that villagers will follow their leaders. Considering the role of elected representatives in case of Panchayati Raj especially Gram Panchayat members, every facet of development work is in the hands of these representatives. This has laid more and more responsibility on the shoulders of leaders to lead and to lead by their 
followers. Gram Panchayat members as the representatives of the people are expected to know the details of the various agricultural development programmes undertaken by government authority. This enables those (Gram Panchayat Members) in motivating and guiding their followers particularly in agricultural development. Taking into consideration the role of Gram Panchayat members there are certain expectations from their followers. Members who are aware and had detailed knowledge about agricultural development programmes should naturally work better for the people; it helps in fulfill the expectations of the people. Hence it is important to search the awareness level of gram panchayat members about agricultural development with the following objective: To study the level of awareness of Gram Panchayat Members about agricultural development programmes.

\section{Materials and Methods}

\section{Sampling plan of the study}

The study was conducted in Azamgarh and Meerut district of Uttar Pradesh. Two blocks were selected randomly from each of the selected districts. Thus a total of four blocks were selected. Namely, Mehnagar and Koilsa blocks from Azamgarh district and Daurala and Mawana blocks from Meerut district. For selecting the sample Gram Panchayats, a list of all the Gram Panchhayats in the selected blocks, procured from the blocks headquarters. Thus, the total 20 Gram Pnachayats ( 5 from each block) were selected randomly. For selecting the gram panchayat members, a list of members from 20 selected gram panchayats were prepared with the help of gram panchayat secretary. All the members of selected 20 gram panchayats were included in the sample. Finally, total 200 gram panchayat members were selected for the present study from all 20 gram panchayats.

\section{Tools and techniques of data collection}

A pre-tested structured interview schedule was prepared. Data was collected by personal interview method.

\section{Statistical tools used}

The respondents were asked to mention their awareness regarding fifteen agricultural development programmes on a three point continuum viz., fully aware, partially aware and unaware. The responses of the members were regarded. The scores 2, 1 and 0 were assigned for fully aware, partially aware and unaware, respectively.

The maximum and minimum score for individual was 30 and 15, respectively. Total scores were summed to get awareness score of individual respondent. The awareness of GPMs was framed on the basis of mean and standard deviation.

\section{Results and Discussion}

\section{Awareness level of gram panchayat members about agricultural development programmes}

The table 1 showed the awareness level of GPMs about different agricultural development programmes that PM Kisan Samman Nidhi Yojana having highest score with ranked I followed by Kisan Credit Card ranked II, Vermin Compost Yojana ranked III, Kisan Call Centre ranked IV, Soil Health Card ranked V, Solar Pump Yojana ranked VI, Schemes of Sugarcane ranked VII, Livestock Insurance Scheme ranked VIII, National Food Security Mission ranked IX, Pradhan Mantri Kisan Sichai Yojana ranked X, Paramparagat krishi Vikash Yojana ranked XI, National Horticulture Mission ranked XII, Mukhya Mantri 
Table.1 Showing Awareness level of gram panchayat members about agricultural programmes $(\mathrm{N}=200)$

\begin{tabular}{|c|c|c|c|c|c|c|}
\hline \multirow[t]{2}{*}{ S.No. } & \multirow{2}{*}{$\begin{array}{l}\text { Agriculture Related } \\
\text { Programmes }\end{array}$} & \multicolumn{3}{|c|}{ Awareness level } & \multirow{2}{*}{$\begin{array}{l}\text { Total } \\
\text { Score }\end{array}$} & \multirow{2}{*}{$\begin{array}{l}\text { Rank } \\
\text { Order }\end{array}$} \\
\hline & & $\begin{array}{l}\text { Fully } \\
\text { Aware }\end{array}$ & $\begin{array}{c}\text { Partially } \\
\text { Aware }\end{array}$ & Unaware & & \\
\hline 1 & Kisan Call Centre & 105 & 52 & 43 & 262 & IV \\
\hline 2 & Kisan Credit Card & 128 & 19 & 53 & 275 & II \\
\hline 3 & Soil Health Card & 98 & 55 & 47 & 251 & $\mathrm{~V}$ \\
\hline 4 & $\begin{array}{l}\text { Pradhan Mantri kisan Sichai } \\
\text { Yojana }\end{array}$ & 92 & 42 & 66 & 226 & $\mathrm{X}$ \\
\hline 5 & $\begin{array}{l}\text { Paramparagat Krishi Vikash } \\
\text { Yojana }\end{array}$ & 88 & 30 & 82 & 206 & XI \\
\hline 6 & Gramin Bhandaran Yojana & 55 & 63 & 82 & 173 & XIV \\
\hline 7 & Livestock Insurance Scheme & 100 & 38 & 62 & 238 & VIII \\
\hline 8 & PM Kisan Samman Nidhi Yojana & 195 & 05 & 00 & 395 & I \\
\hline 9 & Solar Pump Yojana & 97 & 56 & 47 & 250 & VI \\
\hline 10 & National Food Security Mission & 89 & 52 & 59 & 230 & IX \\
\hline 11 & National Horticulture Mission & 77 & 45 & 78 & 199 & XII \\
\hline 12 & $\begin{array}{l}\text { Sub Mission on Agriculture } \\
\text { Mechanization }\end{array}$ & 67 & 22 & 111 & 156 & $\mathrm{XV}$ \\
\hline 13 & Vermin Compost Yojana & 110 & 45 & 45 & 265 & III \\
\hline 14 & $\begin{array}{l}\text { Mukhya Mantri Krishak } \\
\text { Durghatna Kalyan Yojana }\end{array}$ & 78 & 22 & 100 & 178 & XIII \\
\hline 15 & Schemes of Sugarcane & 105 & 30 & 65 & 240 & VII \\
\hline
\end{tabular}

Table.2 Showing the overall level of awareness of GPMs members ( $N=200)$

\begin{tabular}{|c|l|c|c|}
\hline S. No. & Categories & \multicolumn{2}{|c|}{ Respondents } \\
\cline { 3 - 4 } & & Number & Percentage \\
\hline 1. & Low (up to 18) & 35 & 17.50 \\
\hline 2. & Medium (19-24) & 120 & 60.00 \\
\hline 3. & High (25 and above) & 45 & 22.50 \\
\hline & Total & 200 & 100 \\
\hline
\end{tabular}

Min=20.12, S.D. $=3.49$

Krishak Durghatna Kalyan Yojana ranked XIII, Gramin Bhandaran Yojana ranked XIV and Sub Mission on Agriculture Mechanization ranked XV, respectively.

Overall level of awareness of Gram Panchayat Members about agricultural development programmes

It is apparent from the table 2 that the maximum numbers of respondents (60\%) were found having medium level of awareness about agriculture development programmes followed by high level $(22.5 \%)$ and low level (17.5\%) of awareness.

This finding is in line with the observation made by the finding of Deshpande et al., (2013) and Singh et al., (2019). 
References

Bhosale, P.B. (2005). Leadership Role in progressive and less progressive villages of Marathwada. Ph.D. (Agri.) Thesis, Marathwada Agricultural University, Parbhani (M.S.).

Bhambu, S. (1997). Training needs of rural women for Panchayati Raj System. M.Sc. (Agri.) Thesis, CCS Haryana Agricultural University, Hissar.

Chaudhary, R.R., Mokale Mamta and Shinde, P.S. (2004). Role performance by women members in Gram Panchayat. Rural India, 67 (1): 3-5.

Deshpande A.R., Soni M.C and Shekhawat S.S. (2013) Role Performance of Grampanchayat Members in
Agricultural Development Programmes. Indian Research Journal of Extension Education, 13 (2):89-92.

Muley, P.P. (2010). A study on role perception and role performance of elected women members in Gram Panchayat. M.Sc. (Agri.) Thesis, Marathwada Agricultural University, Parbhani.

Singh, R.K., Singh R.P., Singh A.K., Upadhyay S.P., Singh A.P. and Singh C.K. (2019). Role performance of gram panchayat members about agriculture development programmes in Faizabad district of Uttar Pradesh. Journal of Pharmacognosy and Phytochemistry, 8 (2):1885-1889.

\section{How to cite this article:}

Ramvinay Pal, H. C. Singh, Shashank Shekhar Singh and Sunil Kumar. 2020. Level of Awareness of Gram Panchayat Members about Agricultural Development Programmes in Uttar Pradesh, India. Int.J.Curr.Microbiol.App.Sci. 9(10): 2672-2675. doi: https://doi.org/10.20546/ijcmas.2020.910.322 